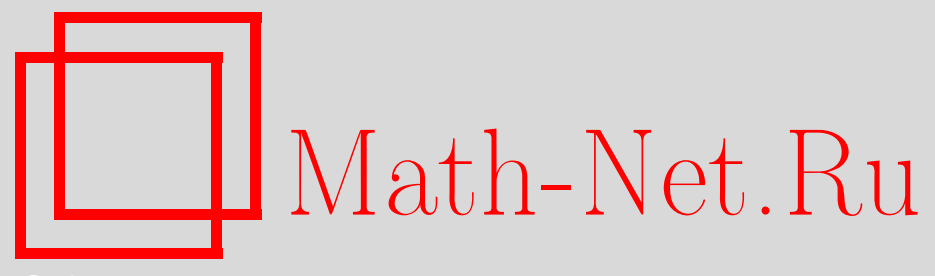

S. S. Vlasova, E. Yu. Prosviryakov, Плоская конвекция вязкой несжимаемой жидкости при заданной теплоотдаче на свободной границе, Вестн. Сам. гос. техн. ун-та. Сер. Физ.-мат. науки, 2016, номер 3, 567-577

DOI: https://doi.org/10.14498/vsgtu1483

Использование Общероссийского математического портала MathNet.Ru подразумевает, что вы прочитали и согласны с пользовательским соглашением

http://www . mathnet.ru/rus/agreement

Параметры загрузки:

IP : 44.207 .124 .84

26 апреля 2023 г., 17:52:04

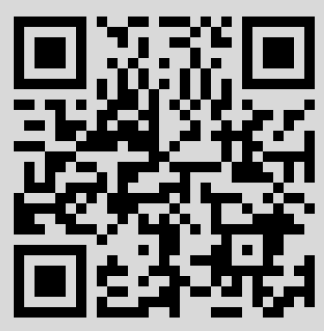


MSC: 76F02, 76F45, 76M45, 76R05, 76U05

\title{
TWO-DIMENSIONAL CONVECTION OF AN INCOMPRESSIBLE VISCOUS FLUID WITH THE HEAT EXCHANGE ON THE FREE BORDER
}

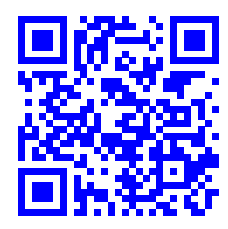

\author{
S. S. Vlasova ${ }^{1}$, E. Yu. Prosviryakov ${ }^{2}$ \\ 1 Kazan National Research Technical University named after A. N. Tupolev, \\ 10, Karl Marx st., Kazan, 420111, Russian Federation. \\ 2 Institute of Engineering Science, Ural Branch of RAS, \\ 34, Komsomolskaya st., Ekaterinburg, 620049, Russian Federation.
}

\begin{abstract}
The exact stationary solution of the boundary-value problem that describes the convective motion of an incompressible viscous fluid in the two-dimensional layer with the square heating of a free surface in Stokes's approach is found. The linearization of the Oberbeck-Boussinesq equations allows one to describe the flow of fluid in extreme points of pressure and temperature. The condition under which the counter-current flows (two counter flows) in the fluid can be observed, is introduced. If the stagnant point in the fluid exists, six non-closed whirlwinds can be observed.
\end{abstract}

Keywords: exact solution, Newton-Rikhmann law, thermal convection, Oberbeck-Boussinesq equations, counter-current flow.

Introduction. The research of the convective flows of an incompressible viscous fluid is caused by a considerable drop of temperature in a wide range of processes connected with the deformation of dissipative environments. The convection induced by the non-uniform heating of incompressible and compressed substances is the most widespread kind of gas dynamics and fluid flows in the Universe. The convective motion of the fluid heated from below in a two-dimensional horizontal layer is one of the most popular subjects of studying. The first example of self-organization of the nonlinear phenomena is Rayleigh-Benard convection. The choice of the two-dimensional layer as the abstract mathematical object is mainly connected with the fact that this geometry can be quite easily realized in an experiment and provides certain conveniences for taking thermal and optical measurements. The two-dimensional horizontal layer is a matter of great

(C) 2016 Samara State Technical University.

Please cite this article in press as:

Vlasova S. S., Prosviry akov E. Yu. Two-dimensional convection of an incompressible viscous fluid with the heat exchange on the free border, Vestn. Samar. Gos. Tekhn. Univ., Ser. Fiz.-Mat. Nauki [J. Samara State Tech. Univ., Ser. Phys. \& Math. Sci.], 2016, vol. 20, no. 3, pp. 567-577. doi: 10.14498/vsgtu1483.

\section{Authors Details:}

Svetlana S. Vlasova (sveta040790@yandex.ru; Corresponding Author), Postgraduate Student, Dept. of Machinery Engineering \& Engineering Graphics.

Evgeny Yu. Prosviryakov (Cand. Phys. \& Math. Sci.; evgen_pros@mail.ru), Leading Researcher, Laboratory of Applied Mechanics. 
importance in connection with the theory of convective stability applications in meteorology, geophysics and astrophysics $[1,2]$.

The first exact solution of the natural convection for a two-dimensional layer of fluid with a constant gradient of the temperature on the borders of the layer is described in the article [3], where two cases of boundary conditions for the velocity are considered. A brief survey of the articles and reviews, in which the possibilities of finding exact solutions to free convection equations and the research of stability of these solutions were studied [4-10], is given in the papers [1,2] and the reference lists.

In the work [5], a method for the description of heat exchange with the localized parabolic heating of the border is offered. This method is offered in the context of the exact solutions class in which velocities linearly depend on horizontal coordinates, and fields of the pressure and temperature are distributed under the square law $[2,6,11]$. In this case, finding the exact solution is reduced to solving the nonlinear system of one-dimensional evolution heat conduction equations like heat conductivity, and stationary equations of the gradient type. When finding the exact solutions, which describe the convective fluid flow [1-10], an ideal heat transfer on the borders is assumed. The aim of the present work is to investigate the motion of a viscous incompressible fluid with heat exchange on the upper boundary.

1. Mathematical model and main equations. The plane layer stationary convection of a viscous incompressible fluid (Fig. 1) can be presented by the system of Oberbeck-Boussinesq equations:

$$
\begin{gathered}
V_{x} \frac{\partial V_{x}}{\partial x}+V_{z} \frac{\partial V_{x}}{\partial z}=-\frac{\partial P}{\partial x}+\nu\left(\frac{\partial^{2} V_{x}}{\partial x^{2}}+\frac{\partial^{2} V_{x}}{\partial z^{2}}\right), \\
V_{x} \frac{\partial V_{z}}{\partial x}+V_{z} \frac{\partial V_{z}}{\partial z}=-\frac{\partial P}{\partial z}+\nu \Delta V_{z}+g \beta T \\
\frac{\partial V_{x}}{\partial x}+\frac{\partial V_{z}}{\partial z}=0 \\
V_{x} \frac{\partial T}{\partial x}+V_{z} \frac{\partial T}{\partial z}=\chi\left(\frac{\partial^{2} T}{\partial x^{2}}+\frac{\partial^{2} T}{\partial z^{2}}\right) .
\end{gathered}
$$

In the system of equations (1), the following designations are introduced: $V_{x}$, $V_{z}$ are the velocities that are parallel to $x$ axis and $z$ axis, respectively; $P$ is the pressure deviation from hydrostatic pressure divided by the constant average fluid density $\rho ; T$ is a deviation from the average temperature; $\nu, \chi, \beta$ are the dissipative coefficients of the kinematic viscosity, heat diffusivity and thermal

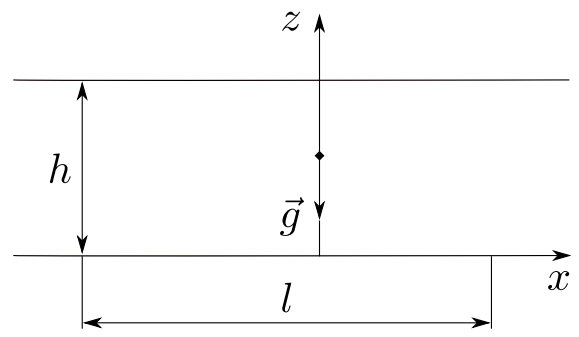

Figure 1. Schematic view of the model problem 
expansion of fluid, respectively; $g$ is the acceleration of gravity;

$$
\Delta=\frac{\partial^{2}}{\partial x^{2}}+\frac{\partial^{2}}{\partial z^{2}}
$$

is the two-dimensional Laplace operator written down in the Cartesian orthogonal coordinate system.

We search the stationary solution of the system (1) in the form of $[2,6,11]$ :

$$
\begin{gathered}
V_{x}=x u(z), \quad V_{z}=w(z), \\
T=T_{0}(z)+T_{11}(z) \frac{x^{2}}{2}, \quad P=P_{0}(z)+P_{11}(z) \frac{x^{2}}{2} .
\end{gathered}
$$

Note that if the temperature $T$ is formally substituted with the concentration function $C$ in the system (1) the solutions (2) are also true for the concentration convection. $\beta$ is the coefficient of concentration fluid extension, in this case.

We substitute the class of solutions (2) in the system of equations (1) and receive the following nonlinear system defining unknown functions $u, w, T_{0}, T_{11}, P_{0}$ :

$$
\begin{gathered}
\nu \frac{d^{2} u}{\partial z^{2}}=u^{2}+w \frac{d u}{\partial z}+P_{11}, \quad \frac{d w}{\partial z}=-u, \\
\frac{d P_{0}}{\partial z}=\nu \frac{d^{2} w}{\partial z^{2}}+g \beta T_{0}-w \frac{d w}{\partial z}, \\
\frac{d P_{11}}{d z}=g \beta T_{11}, \quad w \frac{d T_{0}}{d z}=\chi\left(T_{11}+\frac{d^{2} T_{0}}{d z^{2}}\right), \\
2 u T_{11}+w \frac{d T_{11}}{d z}=\chi \frac{d^{2} T_{11}}{d z^{2}} .
\end{gathered}
$$

We reduce the system of ordinary ninth-order differential equations (3) to the dimensionless form. We introduce the following characteristic geometric scale values as basis [2,6]: $h$ is the transverse characteristic size, $l$ is the axial characteristic size. The units of measurements are: $\Theta$ is for the temperature, $V_{z}$ and $V_{x}$ are for the velocities $\frac{g \beta \Theta h^{4}}{\nu l^{2}}$ and $\frac{g \beta \Theta h^{3}}{\nu l}$ respectively. Thus, the accounting of geometrical anisotropy of the task results in the formation of a flow and availability of two scales for the velocities, since

$$
\frac{g \beta \Theta h^{4}}{\nu l^{2}}=\delta \frac{g \beta \Theta h^{3}}{\nu l}
$$

the pressure for an incompressible fluid divided by the constant density is $g \beta \Theta h$; $\delta=h / l$.

We write down the system (3) in the dimensionless form:

$$
\begin{gathered}
\frac{d P_{11}}{d z}=T_{11}, \quad \frac{d w}{d z}=-u, \quad \operatorname{Gr} \delta^{2}\left(2 u T_{11}+w \frac{d T_{11}}{d z}\right)=\frac{1}{\operatorname{Pr}} \frac{d^{2} T_{11}}{d z^{2}} \\
\operatorname{Gr} \delta^{2} w \frac{d T_{0}}{d z}=\frac{1}{\operatorname{Pr}}\left(\delta^{2}+\frac{d^{2} T_{0}}{d z^{2}}\right), \quad \operatorname{Gr} \delta^{2} w \frac{d w}{d z}=-\frac{d P_{0}}{d z}+\delta^{2} \frac{d^{2} w}{d z^{2}}+T_{0} \\
\operatorname{Gr} \delta^{2}\left(u^{2}+\delta \frac{d u}{d z}\right)=-P_{11}+\delta^{2} \frac{d^{2} u}{d z^{2}}
\end{gathered}
$$


Both dimensionless and dimensional (3) variables and functions in the system (4) are designated by the same symbols. Only dimensionless variables are used further on. In this work

$$
\mathrm{Gr}=\frac{g \beta \Theta h^{5}}{\nu^{2} l^{2}}
$$

is the modified Grashof number.

We find the solution of the system (4) in the extremum points of the temperature. For this purpose we linearize the equations (3). The linearization of the nonlinear system (4) is possible when $\operatorname{Gr} \delta^{2} \ll 1$. In this case, the received exact solutions are fair with any Grashof number they satisfy the assessed value $\mathrm{Gr} \ll 1 / \delta^{2}$ where $\mathrm{Gr} \in\left(0 ; 1 / \delta^{2}\right)$. It should be noted that with an isotropic geometry $(\delta=1)$, we receive the classical criterion of reducing the equations (1) to Stokes equation [11].

The linearized system (3) in the dimensionless form is written as:

$$
\begin{gathered}
\frac{d^{2} T_{11}}{d z^{2}}=0, \quad \frac{d P_{11}}{d z}=T_{11}, \quad \frac{d^{2} u}{d z^{2}}=P_{11}, \quad \frac{d w}{d z}=-u, \\
\frac{d^{2} T_{0}}{d z^{2}}=-\delta^{2} T_{11}, \quad \frac{d P_{0}}{d z}=T_{0}+\delta^{2} \frac{d^{2} w}{d z^{2}} .
\end{gathered}
$$

The equations in the system (5) are written out in the order, the integration of equations is effected.

2. Boundary conditions and exact solutions. The system of the linear differential equations (5) has the exact polynomial solution:

$$
\begin{aligned}
& T_{11}=C_{1} z+C_{2}, \quad P_{11}=C_{1} \frac{z^{2}}{2 !}+C_{2} z+C_{3}, \\
& u=C_{1} \frac{z^{4}}{4 !}+C_{2} \frac{z^{3}}{3 !}+C_{3} \frac{z^{2}}{2}+C_{4} z+C_{5}, \\
& w=-C_{1} \frac{z^{5}}{5 !}-C_{2} \frac{z^{4}}{4 !}-C_{3} \frac{z^{3}}{3 !}-C_{4} \frac{z^{2}}{2 !}-C_{5} z+C_{6}, \\
& T_{0}=-C_{1} \delta^{2} \frac{z^{3}}{3 !}-C_{2} \delta^{2} \frac{z^{2}}{2 !}+C_{7} z+C_{8}, \\
& P_{0}=-2 C_{1} \delta^{2} \frac{z^{4}}{4 !}-2 C_{2} \delta^{2} \frac{z^{3}}{3 !}+\left(C_{7}-\delta^{2} C_{3}\right) \frac{z^{2}}{2}+\left(C_{8}-\delta^{2} C_{4}\right) z+C_{9} .
\end{aligned}
$$

We formulate boundary conditions for finding the constants of integration - the coefficients of polynomials (6). The heat source is introduced on the lower solid bound:

$$
T=A+B x^{2}=\frac{\Theta}{2}\left(1-x^{2}\right)
$$

with dimensionless variables, it is written as:

$$
T=\frac{1}{2}\left(1-x^{2}\right) .
$$

The boundary conditions for defining the constants of integration of dimensionless solutions (5) can be written as:

$$
z=-1: w=u=0, \quad T_{11}=-1, \quad T_{0}=\frac{1}{2} ;
$$




$$
z=0: w=0, \quad P_{11}=0, \quad P_{0}=1, \quad \frac{d T_{0}}{d z}=-\mathrm{Bi} T_{0}, \quad \frac{d T_{11}}{d z}=-\mathrm{Bi} T_{11} .
$$

The no-slip condition is set on the lower bound $(z=-1)$, and the heat exchange under Newton-Rikhman law is set on the free plane layer bound [12]. Bi is Biot number [12]. It is obvious that the integration constants defining the structure of the exact solution (6) by boundary conditions (7) and (8) can be as follows:

$$
\begin{gathered}
C_{3}=C_{6}=0, \quad C_{9}=1 . \\
C_{1}=\frac{\mathrm{Bi}}{\mathrm{Bi}+1}, \quad C_{2}=-\frac{1}{\mathrm{Bi}+1}, \quad C_{4}=\frac{2(4 \mathrm{Bi}+15)}{5 !(\mathrm{Bi}+1)}, \quad C_{5}=\frac{3 \mathrm{Bi}+10}{5 !(\mathrm{Bi}+1)}, \\
C_{7}=\frac{\delta^{2} \mathrm{Bi}(\mathrm{Bi}+3)-3 \mathrm{Bi}(\mathrm{Bi}+1)}{3 !(\mathrm{Bi}+1)^{2}}, \quad C_{8}=\frac{3(\mathrm{Bi}+1)-\delta^{2}(\mathrm{Bi}+3)}{3 !(\mathrm{Bi}+1)^{2}} .
\end{gathered}
$$

Let's substitute (6) with the boundary conditions (7) and (8) into the equations (2), then the expressions of hydrodynamic fields are written in the following form:

$$
\begin{aligned}
& V_{x}=x\left(\frac{\mathrm{B} i z^{4}}{4 !(\mathrm{B} i+1)}-\frac{z^{3}}{3 !(\mathrm{B} i+1)}+\frac{2(4 \mathrm{~B} i+15) z}{5 !(\mathrm{B} i+1)}+\frac{3 \mathrm{~B} i+10}{5 !(\mathrm{B} i+1)}\right), \\
& V_{z}=-\left(\frac{\mathrm{Bi} z^{5}}{5 !(\mathrm{B} i+1)}+\frac{z^{4}}{4 !(\mathrm{Bi}+1)}-\frac{(4 \mathrm{Bi}+15) z^{2}}{5 !(\mathrm{Bi}+1)}-\frac{(3 \mathrm{~B} \mathrm{i}+10) z}{5 !(\mathrm{Bi}+1)}\right), \\
& T=-\frac{\mathrm{Bi} \delta^{2} z^{3}}{3 !(\mathrm{B} i+1)}+\frac{\delta^{2} z^{2}}{2 !(\mathrm{B} i+1)}+\frac{\delta^{2} \mathrm{Bi}(\mathrm{Bi}+3)-3 \mathrm{Bi}(\mathrm{B} i+1)}{3 !(\mathrm{B} i+1)^{2}} z+ \\
& +\frac{3(\mathrm{~B} i+1)-\delta^{2}(\mathrm{Bi}+3)}{3 !(\mathrm{B} i+1)^{2}}+\frac{x^{2}(\mathrm{Bi} z-1)}{2 !(\mathrm{B} i+1)}, \\
& \begin{aligned}
& P=-\frac{2 \mathrm{~B} i \delta^{2} z^{4}}{4 !(\mathrm{B} i+1)}+\frac{2 \delta^{2} z^{3}}{3 !(\mathrm{B} i+1)}+\frac{2\left(\delta^{2} \mathrm{~B} i(\mathrm{~B} i+3)-3 \mathrm{~B} i(\mathrm{~B} i+1)\right) z^{2}}{4 !(\mathrm{B} i+1)^{2}}+ \\
&+\left(\frac{3(\mathrm{Bi}+1)-\delta^{2}(\mathrm{~B} \mathrm{i}+3)}{3 !(\mathrm{B} i+1)^{2}}-\frac{2(4 \mathrm{~B} i+15) \delta^{2}}{5 !(\mathrm{B} i+1)}\right) z+ \\
&+1+\left(\frac{\mathrm{B} i z^{2}}{2 !(\mathrm{B} i+1)}-\frac{z}{\mathrm{~B} i+1}\right) \frac{x^{2}}{2} .
\end{aligned}
\end{aligned}
$$

3. Analysis of the plane convective motion of the fluid. Since the solutions (6) of the system of equations (5)are polynomial, the analysis of flows can always be converted to the solution of the generalized Raus-Gurvits problem. We consider the characteristic properties of the velocities depending on the value of Biot number. Considering the boundary conditions (6) and (7), we find out that the variety of the function's values can be presented in the following form:

$$
u=(z+1) f(z)=(z+1)\left(\frac{\mathrm{Bi} z^{3}}{4 !(\mathrm{Bi}+1)}-\frac{(\mathrm{Bi}+4) z^{2}}{4 !(\mathrm{Bi}+1)}+\right.
$$




$$
\left.+\frac{(\mathrm{Bi}+4) z}{4 !(\mathrm{Bi}+1)}+\frac{3 \mathrm{~B} \mathrm{i}+10}{5 !(\mathrm{B} \mathrm{i}+1)}\right) .
$$

The function $f$ is a cubic polynomial with the coefficients depending on number Bi under the linear-fractional law. We investigate the spectral properties of a polynom $f$ on the domain of the definition. It is known that the function contains an odd number of zero values (the quantity of stagnant points of the flow) when an inequality is being solved:

$$
f(-1) f(0)<0
$$

and an even number when the opposite inequality is being solved. Thus, the function $f$ has the only one solution in the interval with

$$
\text { Bi } \in(-\infty ;-10 / 3) \cup(-5 / 2 ;-1) \cup(-1 ;+\infty) .
$$

When $\mathrm{Bi}=0$, the assumed cubic polynomial degenerates into a linear function. Two solutions are possible in the one case with $\mathrm{Bi} \in(-10 / 3 ;-5 / 2)$. Let's consider graphs of the stream function and vorticity when $B i=-2.7$ (Fig. 2) and $\mathrm{Bi}=-2$ (Fig. 3). The expressions are assumed for the stream function of the velocity:

$$
\psi=-x z(z+1)^{2}\left(-\frac{\mathrm{B} i z^{2}}{5 !(\mathrm{B} i+1)}+\frac{(2 \mathrm{~B} i+5) z}{5 !(\mathrm{B} i+1)}-\frac{3 \mathrm{~B} i+10}{5 !(\mathrm{B} i+1)}\right)
$$

and vorticity:

$$
\Omega_{y}=x\left(\frac{\mathrm{Bi} z^{3}}{3 !(\mathrm{B} i+1)}-\frac{z^{2}}{2 !(\mathrm{B} \mathrm{i}+1)}+\frac{2(4 \mathrm{~B} \mathrm{i}+15)}{5 !(\mathrm{B} \mathrm{i}+1)}\right) .
$$

Investigating the localization of the polynom $f$ roots with the values of numbers $\mathrm{Bi}=-10 / 3$ and $\mathrm{Bi}=-5 / 2$, we find out that the function takes the zero
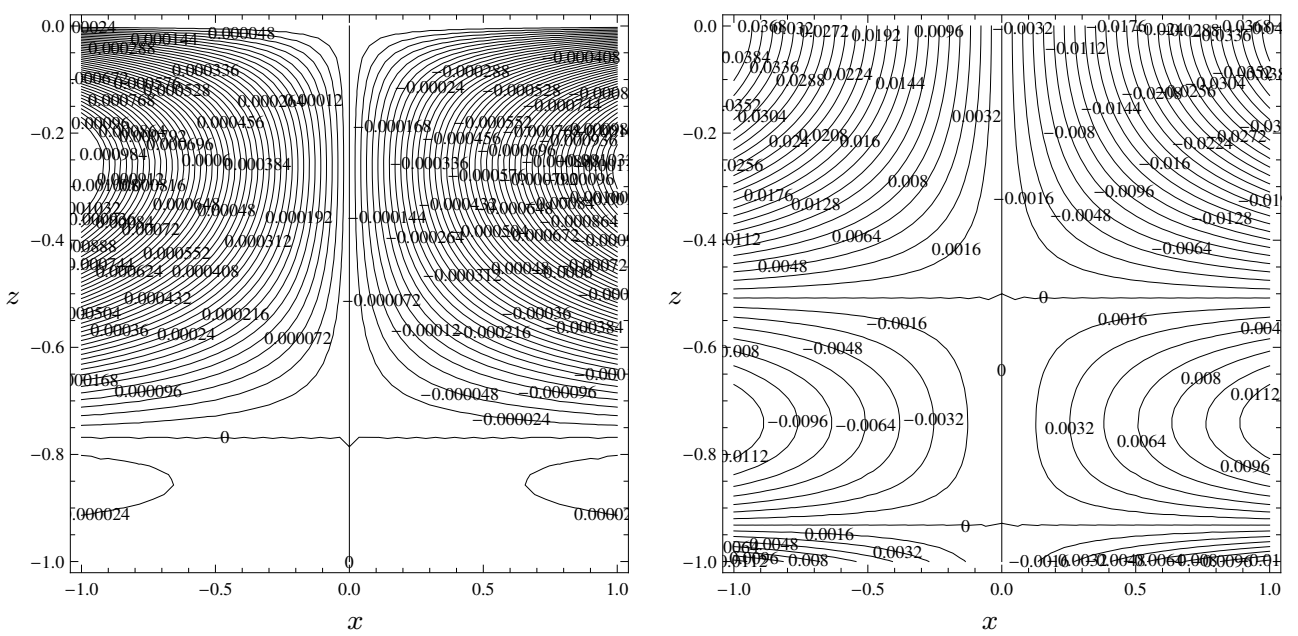

Figure 2. Isolines of the current function (left) and the function of vorticity (right) with $\mathrm{Bi}=-2.7$ 

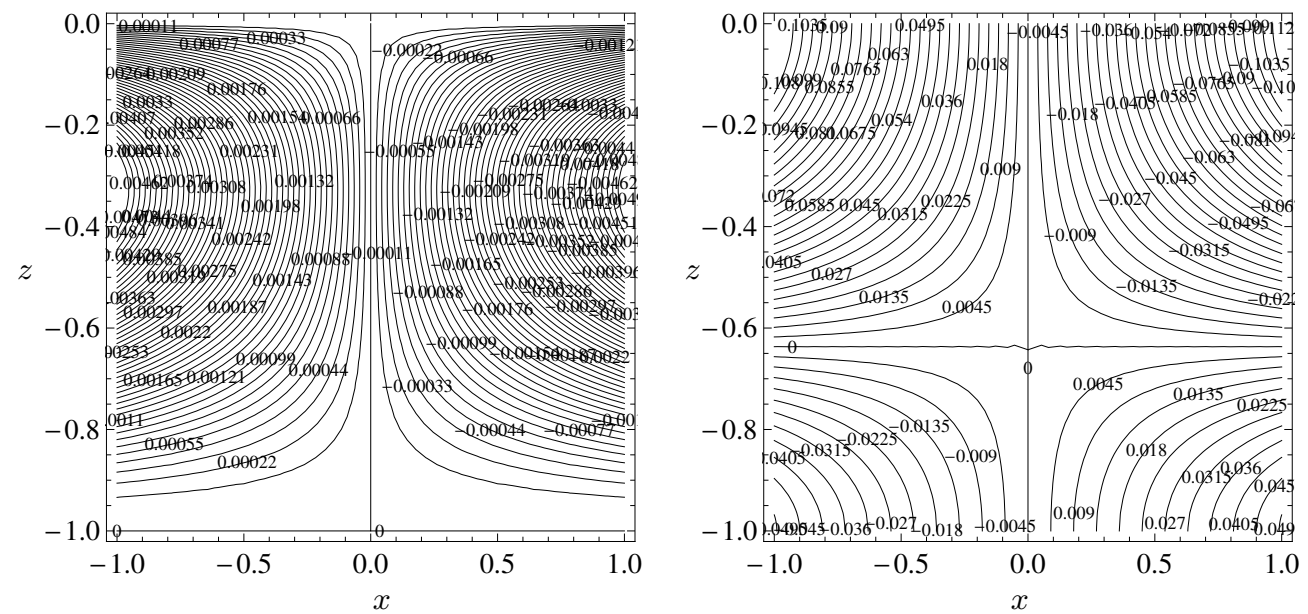

Figure 3. Isolines of the current function (left) and the function of vorticity (right) with $B i=-2$

values in the intervals of definition $z=0, z=-(1+\sqrt{21}) / 10$ and $z=-1$, $z=(1-\sqrt{6}) / 5$ respectively.

Let's note that for the velocity there is a point different from $z=-1$ in which the velocity does not depend on the values of Biot number. To prove this statement, we take two Biot numbers not equal among one another and substitute them in the expression for a gradient $u$. Subtracting one polynomial function from another, we receive the equation for the definition of this point within the interval $[-1 ; 0]$ :

$$
5 z^{4}+20 z^{3}-22 z-7=0 .
$$

Calculating the roots of this equation, we receive the point in which the velocity does not depend on Biot number, and the value of velocity is:

$$
z=-0.370734, \quad u(-0.370734)=0.01929 .
$$

Now we consider the characteristic properties of the velocity parallel to an axis of $z$-coordinates. Its value as well as the value of velocity $V_{x}$ does not depend on parameter $\delta$. If we consider the boundary conditions (7) and (8), we find out that the multiplicity of the function $V_{z}$ values can be presented in the following form:

$$
w=z(z+1)^{2} f(z)=z(z+1)^{2}\left(-\frac{\mathrm{B} \mathrm{i} z^{2}}{5 !(\mathrm{B} \mathrm{i}+1)}+\frac{(2 \mathrm{~B} \mathrm{i}+5) z}{5 !(\mathrm{B} \mathrm{i}+1)}-\frac{3 \mathrm{~B} \mathrm{i}+10}{5 !(\mathrm{B} \mathrm{i}+1)}\right) .
$$

The function $f$ is a square polynomial with the coefficients depending on Bi under the fractional-linear function. The function $f$ has the only one root within the interval $[-1 ; 0]$ with $\mathrm{Bi} \in(-10 / 3 ;-5 / 2)$. If $\mathrm{B} \mathrm{i}=0$, the initial square polynomial degenerates into a linear function. When an inequality $f(-1) f(0)>0$ is being solved in the interval $[-1 ; 0]$ no roots are found. Analyzing the arrangement of square polynomial roots $f$ with the values of numbers $\mathrm{Bi}=-10 / 3$ and $\mathrm{Bi}=-5 / 2$, we find out that the function takes these values in the intervals of definition $z=0$ and $z=-1$, respectively. 
Let's consider the additive components of the temperature. The square additive component $T_{11}$ is distributed under the linear law. The variety of the function $T_{11}$ values for $z \in[-1 ; 0]$ takes negative values with Biot $\mathrm{Bi} \in[-1 ; 0)$. The received $T_{11}$ solution takes up the constant value when $\mathrm{Bi}=0: T_{11}=-1$. The additive component is monotonously increasing with $\mathrm{Bi} \in(-\infty ;-1) \cup(0 ;+\infty)$, otherwise it is monotonously decreasing. Function $T_{11}$ vanishes in the interval of the definition in the point $z=1 / \mathrm{Bi}$ with $\mathrm{Bi} \in[-1 ; 0)$.

Now let's consider the properties of the background temperature and pressure. The background temperature can be presented in the following form:

$$
T_{0}=\mathrm{Bi} C_{2} \delta^{2} \frac{z^{3}}{3 !}-C_{2} \delta^{2} \frac{z^{2}}{2 !}-\mathrm{Bi} C_{8} z+C_{8} .
$$

The existence of an odd number of solutions is equivalent to an inequality being solved:

$$
T_{0}(-1) T_{0}(0)=C_{8}\left(C_{8}(\mathrm{Bi}+1)-\frac{C_{2} \delta^{2}}{3 !}(\mathrm{Bi}+3)\right)<0 .
$$

Due to the boundary conditions (7) and (8), the temperature can be presented in another form:

$$
\begin{aligned}
T_{0}=\frac{1}{2}+\frac{(z+1)}{3 !(\mathrm{Bi}+1)^{2}}( & -z^{2} \mathrm{Bi} \delta^{2}(\mathrm{Bi}+1)+z \delta^{2}(\mathrm{Bi}+1)(\mathrm{Bi}+3)- \\
\left.-3 \mathrm{Bi}(\mathrm{Bi}+1)-\delta^{2}(\mathrm{Bi}+3)\right)= & \\
& =\frac{1}{2}+\frac{(z+1)}{3 !(\mathrm{Bi}+1)^{2}} g(z) .
\end{aligned}
$$

Let's investigate the function $g(z)$. The function $g(z)$ is a square polynomial function depending on two parameters: $\delta$ and $\mathrm{Bi}$. The function $g(z)$ takes a zero value in the interval of the definition when an inequality is being solved:

$g(-1) g(0)=\left(3 \mathrm{Bi}+3 \mathrm{Bi}^{2}+3 \delta^{2}+\mathrm{Bi} \delta^{2}\right)\left(3 \mathrm{Bi}+3 \mathrm{Bi}^{2}+6 \delta^{2}+6 \mathrm{Bi} \delta^{2}+2 \mathrm{Bi}^{2} \delta^{2}\right)<0$.

The function $g(z)$ has two solutions when the system of inequalities is being solved:

$$
\left\{\begin{aligned}
D & >0 \\
g(0) g(-1) & >0
\end{aligned}\right.
$$

$D$ is the discriminant of a quadratic equation. If the minimum of the function $T_{0}$ is not more than 0.5 , the number of zeros of the function $T_{0}$ is equal to the number of zeros.

Further on, additive components of the pressure are analyzed. We provide isolines of the temperature and pressure when $\mathrm{Bi}=-2$ and $\delta=1$ (Fig. 4) and when $\mathrm{Bi}=-0.4$ and $\delta=0.48$ (Fig. 5).

It is obvious that the square law change of $P_{11}$ converts into a linear dependence $P_{11}=-z$ when $\mathrm{Bi}=0$. The function $P_{11}$ reduces to zero within the interval $[-1 ; 0)$ in the point $z=2 / \mathrm{Bi}$. Since the square curve turns into a linear dependence, the function $P_{11}$ monotonously decreases.

Let's consider the background pressure function $P_{0}(z)$. The function $P_{0}(z)$ is a quartic polynomial depending on two parameters: $\delta$ and $\mathrm{Bi}$. The function 

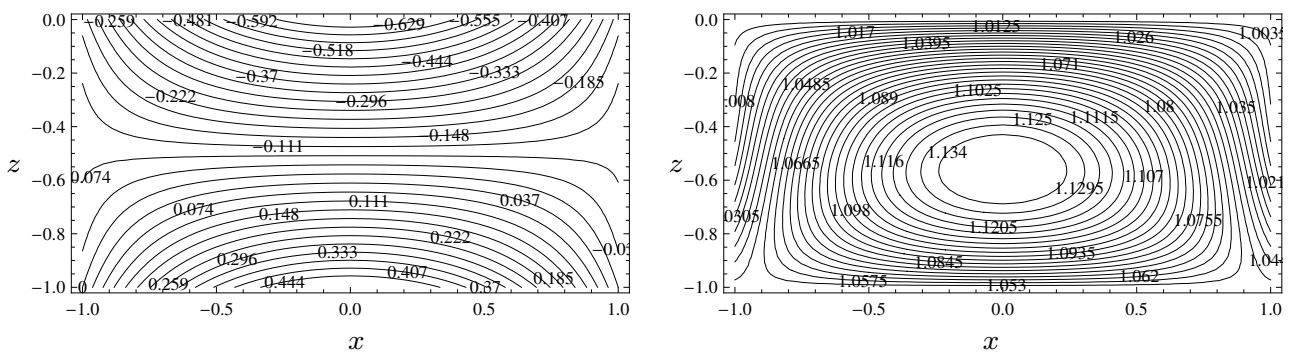

Figure 4. Isolines of the functions of temperature and pressure with $\mathrm{Bi}=-2$ and $\delta=1$
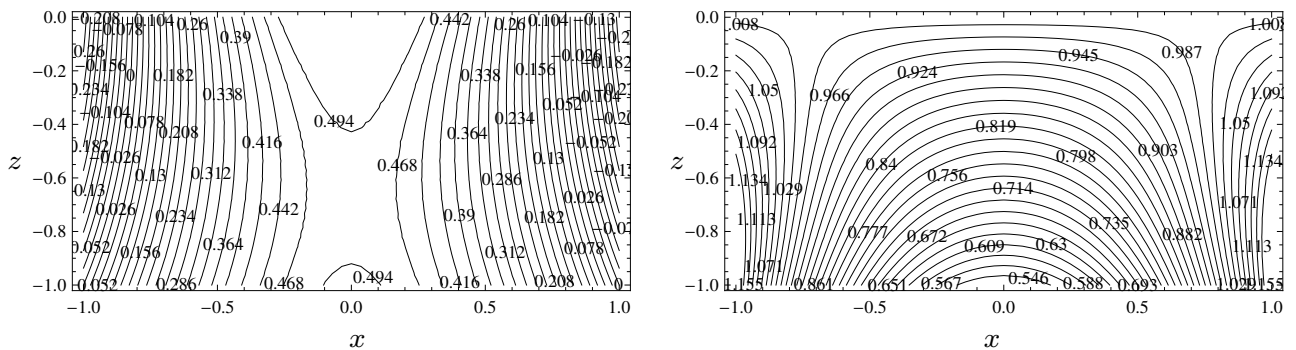

Figure 5. Isolines of the function of temperature pressure with $\mathrm{Bi}=-0.4$ and $\delta=0.48$

$P_{0}(z)$ takes one zero value in the interval of the definition $z \in[-1 ; 0]$ when the inequality is being solved:

$$
P(-1) P(0)<0
$$

The function of the pressure comes up to the maximum with some values of parameters $\delta$ and $\mathrm{Bi}$ in the considered interval. The existence of the extremum points in the interval of the definition $z \in[-1 ; 0]$ is confirmed by the inequality solution:

$$
P^{\prime}(-1) P^{\prime}(0)<0
$$

Thus, the structure of the function for the temperature shows that some locally hyperbolic level lines exist. In other words, they can not be closed with any Biot number and $\delta$ values. The local ellipticity isolines of the pressure can be observed in a rather wide range of the dimensionless complexes defining the topology of the fluid flow.

Conclusion. In this paper the convective motion of the two-dimensional flow of a viscous incompressible fluid under the Newton-Rikhman law on one of the borders of an infinite fluid layer in Stokes's approach has been analyzed.

The assessed value of the function that makes the linearization of the NavierStokes equation in the Oberbeck-Boussinesq approach possible has been obtained. It is shown that the considered system of ordinary differential equations received within the announced class of exact solutions, exactly describes a fluid flow in extreme points of the temperature and pressure. The values when counter-current flows in the fluid can be observed, are found. It is shown that depending on similarity numbers in fluid, a different number of whirlwinds and the local ellipticity of pressure isolines can be observed. 
Declaration of Financial and Other Relationships. This work was supported by the Foundation for Assistance to Small Innovative Enterprises in Science and Technology (the UMNIK program); the agreement no. 8389 GU2/2015. Each author has participated in the article concept development and in the manuscript writing. The authors are absolutely responsible for submitting the final manuscript in print. Each author has approved the final version of manuscript. The authors have not received any fee for the article.

\section{ORCIDs}

Svetlana S. Vlasova: http://orcid.org/0000-0002-1458-8760

Evgeny Yu. Prosviryakov: http://orcid.org/0000-0002-2349-7801

\section{REFERENCES}

1. Getling A. V. Formation of spatial structures in Rayleigh-Bénard convection, Sov. Phys. Usp., 1991, vol. 34, no. 9, pp. 737-776. doi: 10.1070/pu1991v034n09abeh002470.

2. Aristov S. N., Prosviryakov E. Yu. On one class of analytic solutions of the stationary axisymmetric convection Bénard-Maragoni viscous incompreeible fluid, Vestn. Samar. Gos. Tekh. Univ., Ser. Fiz. Mat. Nauki [J. Samara State Tech. Univ., Ser. Phys. \& Math. Sci.], 2013, no. 3(32), pp. 110-118 (In Russian). doi: 10.14498/vsgtu1205.

3. Birikh R. V. Thermocapillary convection in a horizontal layer of liquid, J. Appl. Mech. Tech. Phys., 1966, vol. 7, no. 3, pp. 43-44. doi: 10.1007/bf00914697.

4. Andreev V. K., Bekezhanova V. B. Stability of non-isothermal fluids (Review), J. Appl. Mech. Tech. Phys., 2013, vol. 54, no. 2, pp. 171-184. doi: 10.1134/s0021894413020016.

5. Aristov S. N., Shvarts K. G. Vikhrevye techeniya advektivnoi prirody vo vrashchayushchemsya sloe zhidkosti [Advective Eddy Flows in a Rotating Liquid Layer]. Perm, Perm. Gos. Univ., 2006 (In Russian).

6. Aristov S. N., Shvarts K. G. Vikhrevye Techeniya v tonkikh sloyakh zhidkosti [Eddy Flows in Thin Liquid Layers]. Kirov, Vyat. Gos. Univ, 2011 (In Russian).

7. Aristov S. N., Shvarts K. G. Convective heat transfer in a locally heated plane incompressible fluid layer, Fluid Dynamics, 2013, vol.48, no.3, pp. 330-335. doi:10.1134/ s001546281303006x.

8. Goncharova O. N., Rezanova E. V. Modeling of two-layer fluid flows with evaporation at the interface in the presence of the anomalous thermocapillary effect, J. Sib. Fed. Univ. Math. Phys., 2016, vol. 9, no. 1, pp. 48-59. doi : 10.17516/1997-1397-2016-9-1-48-59.

9. Efimova M. V. On one two-dimensional stationary flow of a binary mixture and viscous fluid in a plane layer, J. Sib. Fed. Univ. Math. Phys., 2016, vol. 9, no. 1, pp. 30-36. doi: 10. 17516/1997-1397-2016-9-1-30-36.

10. Goncharova O. N., Kabov O. A., Pukhnachov V. V. Solutions of special type describing the three dimensional thermocapillary flows with an interface, Int. J. Heat Mass Transfer., 2012, vol. 55, no.4, pp. 715-725. doi: 10.1016/j.ijheatmasstransfer.2011.10.038.

11. Aristov S. N., Prosviryakov E. Yu. A New Class of Exact Solutions for Three Dimensional Thermal Diffusion Equations, Theor. Found. Chem. Eng., 2016, vol. 50, no. 3, pp. 286-293. doi: 10.1134/s0040579516030027.

12. Gershuni G. Z., Zhukhovitskii E. M. Konvektivnaya Ustoichivost' Neszhimaemoi Zhidkosti [Convective Stability of An Incompressible Fluid]. Moscow, Nauka, 1972 (In Russian).

Received 13/III/2016;

received in revised form $25 / \mathrm{V} / 2016$;

accepted 09/IX/2016. 
Вестн. Сам. гос. техн. ун-та. Сер. Физ.-мат. науки. 2016, 2016. Т. 20, № 3. С. $567-577$

\title{
УДК 532.51
}

\section{ПЛОСКАЯ КОНВЕКЦИЯ ВЯЗКОЙ НЕСЖИМАЕМОЙ ЖИДКОСТИ ПРИ ЗАДАННОЙ ТЕПЛООТДАЧЕ НА СВОБОДНОЙ ГРАНИЦЕ}

\author{
С. С. Власова ${ }^{1}$, Е. Ю. Просвиряков ${ }^{2}$ \\ 1 Казанский национальный исследовательский \\ технический университет им. А. Н. Туполева, \\ Россия, 420111, Казань, ул. Карла Маркса, 10. \\ 2 Институт машиноведения УрО РАН, \\ Россия, 620049, Екатеринбург, ул. Комсомольская, 34.
}

\begin{abstract}
Аннотация
Найдено точное стационарное решение краевой задачи, описывающее конвективное движение вязкой несжимаемой жидкости в плоском слое при квадратичном нагреве свободной поверхности в приближение Стокса. Линеаризация уравнений Обербека-Буссинеска позволяет описать движение жидкости в точках экстремумов давления и температуры. Выведено условие, при котором наблюдается противотечение (два встречных потока) в жидкости. При наличии застойной точки в жидкости наблюдается шесть незамкнутых вихрей.
\end{abstract}

Ключевые слова: точное решение, закон Ньютона-Рихмана, тепловая конвекция, уравнения Обербека-Буссинеска, противотечение.

Декларация о финансовых и других взаимоотношениях. Работа выполнена при поддержке фонда содействия развитию малых форм предприятий в научно-технической сфере (программа УМНИК), договор № 8389 ГУ2/2015. Все авторы принимали участие в разработке концепции статьи и в написании рукописи. Авторы несут полную ответственность за предоставление окончательной рукописи в печать. Окончательная версия рукописи была одобрена всеми авторами. Авторы не получали гонорар за статью.

\section{ORCIDs}

Светлана Сергеевна Власова: http://orcid.org/0000-0002-1458-8760

Евгений Юрьевич Просвиряков: http://orcid.org/0000-0002-2349-7801

Поступила в редакцию 13/III/2016;

в окончательном варианте $-25 / \mathrm{V} / 2016$;

принята в печать - 09/IX/2016.

(C) 2016 Самарский государственный технический университет.

\section{Образец для цитирования}

Vlasova S. S., Prosviry akov E. Yu. Two-dimensional convection of an incompressible viscous fluid with the heat exchange on the free border // Вестн. Сам. гос. техн. ун-та. Сер. Физ.-мат. науки, 2016. Т. 20, № 3. С. 567-577. doi: 10.14498/vsgtu1483.

\section{Сведения об авторах}

Светлана Сергеевна Власова (sveta040790@yandex.ru; автор, ведущий переписку), аспирант, каф. машиноведения и инженерной графики.

Евгений Юръевич Просвиряков (к.ф.-м.н.; evgen_pros@mail.ru), ведущий научный сотрудник, лаб. прикладной механики. 